\title{
Analisis Sistem Pengendalian Manajemen untuk Peningkatan Kinerja Manajemen Pada Perusahaan Keluarga Tahu Mekar Group
}

\author{
Dosen Pengampu : R. Gesah Mukti P, SE.Ak, M.M \\ ANDARA MUHLISIDINA 2060301200016 \\ LULUK YULIYANA 1960301100054 \\ DENNISA RACHMA 1960301100033
}

\begin{abstract}
Abstrak
Penelitian ini bertujuan untuk mengetahui pengendalian manajemen yang diterapkan pada perusahaan keluarga sehingga dapat meningkatkan kinerja manajemen. Penelitian ini merupakan penilitian dengan pendekatan kualitatif . objek penelitian ini adalah Tahu Mekar Group yang berlokasi di Ngunut. Metode pengumpulan data yang digunakan yaitu wawancara, observasi dan analisis dokumen. Hasil dari penelitian ini menunjukkan bahwa peningkatan kinerja yang dicapai perusahaan keluarga memang cukup dipengaruhi dari pengendalian manjemen yang kurang disadari keberadaannya.
\end{abstract}

Keyword: sistem pengendalian manajemen, kinerja manajemen, perusahaan keluarga

\section{Abstract}

This study aims to determine the management control is applied to the family firm so that it can affect the performance of management. This research is qualitative approach. The object of this research is Tahu Mekar Group that located in Ngunut. Data collection methods used were interviews, observation and document analysis. Results from this study indicate that the performance of management improvement achieved is quite affected family company of the Management control is less aware ofits existence. Keyword: management control system, performance of management, family firm 


\section{Pendahuluan}

Mayoritas perusahaan di Indonesia merupakan perusahaan keluarga, lebih dari 95 persen bisnis di Indonesia merupakan perusahaan yang dimiliki maupun dikendalikan oleh keluarga. Perusahaan-perusahaan keluarga tersebut banyak memberikan kontribusi bagi negara. Berdasarkan data Biro Pusat Statistik, perusahaan keluarga diIndonesia merupakan perusahaan swasta yang mempunyai kontribusi besar terhadap Produk Domestik Bruto yaitu mencapai 82,44\%.

Salah satunya adalah Home industri tahu mekar bisnis rumahan yang berorientasi pada keuntungan untuk membuka lapangan pekerjaan, untuk meningkatkan kesejahteraan pemilik usaha dan karyawan, serta untuk mengembangkan usaha lebih lanjut. Dengan adanya home industri tahu, dapat membuka lapangan pekerjaan bagi masyarakat desa, yang tentunya dapat mengurangi tingkat pengangguran di desa. Dalam mengembangkan usaha dan memiliki banyak konsumen, pasti kualitas produk dan harga menjadi hal yang sangat penting. Kualitas produk merupakan hal yang sangat penting dalam pemasaran agar mendapat kepercayaan dari pelanggan. Kualitas produk dapat diartikan sebagai kemampuan produk tersebut untuk menjalankan fungsinya termasuk ketepatan, keawetan, kemudahan ketika akan digunakan atau diperbaiki, serta kemampuan produk lainnya yang bernilai. Sedangkan harga merupakan sejumlah uang yang dibebankan atas suatu barang atau jasa dimana konsumen menukarkan manfaat harga atas faktor penting yang mempengaruhi suatu pembelian. Harga dapat pula diartikan sebagai nilai suatu produk atau jasa yang diukur menggunakan sejumlah uang yangmana berdasarkan nilai tersebut seseorang bersedia memberikan produk atau jasa yang ia punya untu dimiliki orang lain.

Harga menjadi ukuran bagi konsumen untuk menilai kualitas suatu produk. Produk yang mempunyai kualitas baik, maka harganya lebih mahal apabila dibandingkan dengan produk yang mempunyai kualitas biasa-biasa saja. Harga termasuk strategi dalam pemasaran. Apabila harga produk yang ditetapkan terlalu mahal maka produk tersebut tidak akan terjangkau oleh pasar dan minat konsumen terhadap produk menjadi rendah, sedangkan jika harga terlalu murah yang terjadi yaitu produsen akan sulit mendapatkan keuntungan dan memicu konsumen memiliki persepsi terhadap produk yang ditawarkan tersebut mempunyai kualitas yang rendah. Apabila harga dan kualitas yang ditawarkan sesuai dengan keinginan pelanggan, maka pelanggan akan memakai produk tersebut. 
Secara umum, apabila seorang pelanggan semakin lama bertahan pada suatu industri atau perusahaan, maka semakin berharga pelanggan tersebut. Para pelanggan lama biasanya akan melakukan pembelian lebih banyak. Pelanggan lama juga dapat mempengaruhi dan mengajak pelanggan baru untuk membeli produk yang ditawarkan.

Terdapat beberapa stigma yang menyatakan bahwa perusahaan keluarga sering tidak professional, tidak bisa memisahkan kepentingan keluarga dan kepentingan bisnis, lebih mengutamakan hubungan keluarga daripada kinerja, dan memiliki sistem pengendalian yang tidak terkontrol. Namun eksistensi perusahaan keluarga selalu mengalami perkembangan yang cukup baik. Hal ini bisa jadi disebabkan karena kebanyakan perusahaan keluarga lebih mementingkan hubungan antar keluarga dalam perusahaan dan memilih untuk menjalankan perusahaan secara luwes dibandingkan dengan menerapkan sistem pengendalian yang professional seperti perusahaan publik akan tetapi tidak menimbulkan hubungan yang nyaman antara karyawan seperti pada perusahaan keluarga.

Keluwesan dalam penerapan pengendalian ini umumnya mendorong para karyawan memiliki loyalitas tinggi terhadap perusahaan. (Purnama, 2013) menyatakan bahwa gaya kepemimpinan dan sistem pengendalian memiliki pengaruh positif terhadap loyalitas karyawan pada perusahaan kelurga, hal ini tidak terlepas dari penanaman nilai-nilai prinsip oleh pimpinan. Secara tidak langsung karyawan yang memiliki loyalitas tinggi akan mendorong peningkatan kerja karyawan. Saat kerja karyawan meningkat hal ini bisa jadi sebagai indikator bahwa kinerja manajemen sudah sangat efektif dan efisien. Secara teori, dalam perusahaan publik kinerja manajemen akan menjadi lebih baik apabila setiap aspek dikendaliakan, halini bertujuan untuk meminimalisir tindak kecurangan ataupun kegagalan dalam proses operasional sehingga celah perusahaan untuk mengalami kerugianpun semakin sedikit. Berbeda dengan perusahaan keluarga yang lebih mengedepankan aspek kekeluargaan dalam bekerja, sehingga cenderung lebih memilih menjalin hubungan baik diantara para karyawan.

Penerapan sistem pengendalian manajemen yang baik dalam suatu perusahaanakan menghasilkan dampak positif untuk perkembangan usaha. Akan tetapi, dalam perusahaan keluarga seringkali sistem pengendalian manajemem dikesampingkan tapiperusahaan tetap mengalami perkembangan usaha yang cukup signifikan. Seperti yang terjadi dalam Tahu Mekar Group. Tahu Mekar Group merupakan perusahaan keluarga yang memproduksi makan olahan yakni tahu dan berlokasi di Ngunut.

Home industri tahu ialah salah satu bisnis yang memiliki penghasilan dengan 
keuntungan yang tinggi. Tahu menjadi salah satu makanan pokok bagi setiap individu, karena selain bernutrisi juga harganya terjangkau. Desa Sumberejo Kulon mendapat julukan sebagai kampung tahu, karena banyak warga desa yang menjadi produsen tahu. Jumlah produsen tahu di Desa Sumberejo Kulon yaitu sebanyak 20 home industri. Dengan adanya jumlah industri tahu semakin banyak, menyebabkan bertambahnya pilihan produk tahu bagi konsumen. Tentunya para konsumen atau pelanggan akan memilih industri tahu dengan memperhatikan kualitas, harga, dan juga pelayanan. Oleh karena itu pemilik industri tahu harus memperhatikan kualitas produk, harga, dan juga layanan yang baik agar dapat bersaing dengan industri tahu lainnya. Di Desa Sumberejo Kulon terdapat 20 home industri tahu dimana masing-masing memiliki pelanggan yang lumayan banyak dan dari 20 home industri tahu tersebut yang paling banyak diminati adalah milik Bapak Reni. Melihat dari banyaknya pelanggan dalam membeli tahu di tempat Bapak Reni, peneliti ingin mengetahui apakah para pelanggan tersebut memang menyukai produk tahu yang diproduksi atau karena harga yang ditawarkan lebih murah atau ada faktor lain yang mempengaruhi pelanggan dalam membeli tahu mekar yang diproduksi oleh Bapak Reni.

Penelitian yang dilakukan oleh Mariyana, (Mariyana, Karolin, Wiyono Pontjoharyo., 2013) menjelaskan bahwa sistem pengendalian manajemen dipengaruhi oleh gaya kepemimpinan seseorang. Selain itu, hasil penelitian dari Dewantoro menyatakan bahwa secara parsial terdapat pengaruh signifikan antara tingkat kekuatan keluarga terhadap kinerja perusahaan. Berdasrkan pemaparan masalah di atas maka dilakukan penelitian lebih lanjut tentangsistem pengendalian manajemen yang diterapkan pada perusahaan keluarga yaitu Tahu Mekar Group sehingga dapat mempengaruhi kinerja manajemen.

\section{Landasan Teori}

\section{Pengertian Sistem}

Sistem adalah suatu kegiatan yang telah ditentukan caranya dan biasanya dilakukan berulang-ulang. Dapat dikatakan bahwa sistem berupa hal yang ritmis, berulang kali terjadi atau langkah-langkah terkoordinasi yang dimaksudkan untuk mencapai tujuan tertentu. Menurut Marciariello dalam (Husein,dkk 2003:3)

\section{Manajemen}


Manajemen adalah proses perencanaan, pengorganisasian, pengarahan, dan pengawasan usaha-usaha para anggota organisasi dan penggunaan sumber daya, sumber daya lainnya agar mencapai tujuan organisasi yang telah ditetapkan.

\section{Sistem Pengendalian Manajemen}

(Anthony dan Govindrajan, 2002) menyebutkan bahwa Sistem Pengendalian Manajemen adalah suatu alat atau cara yang terstruktur yang digunakan oleh manajer untuk memastikan bahwa orang-orang yang diawasinya mengimplementasikan strategi yang dimaksudkan. Sedangkan menurut (Merchant Kenneth A. dan Van der Stede, 2014 : 6) mendefinisikan sistem pengendalian manajemen adalah sistem pengaturan yang melibatkan umpan balik tunggal yang hampir sama dengan alat pengatur panas yang mengatur suhu, membandingkan ukuran dengan standar yang diinginkan, dan jika diperlukan melakukan tindakan koreksi.

Sehingga dapat dikatakan sistem pengendalian manajemen adalah suatu sistem yang saling berhubungan satu dengan yang lainnya untuk mencapai tujuan yang telah ditentukan oleh perusahaan.

Berdasarkan (Anthony dan Govindrajan, 2002: 1) terdapat elemen - elemen sistem pengendalian dan setiap sistem pengendalian sedikitnya memiliki empat elemen, yaitu :

1. Pelacak atau sensor adalah sebuah perangkat yang mengukur apa yang sesungguhnya terjadi dalam proses yang sedang dikendalikan.

2. Penaksiran (assessor) yaitu suatu perangkat yang menentukan signifikasi dari peristiwa aktual dengan membandingkannya dengan beberapa standar atau ekspektasi dari apa yang seharusnya terjadi.

3. Effector yaitu suatu perangkat yang mengubah perilaku jika assessor mengindikasikan kebutuhan yang perlu dipenuhi.

4. Jaringan komunikasi yaitu perangkat yang meneruskan informasi antara detector dan assesor dan antara assesor dengan effector.

\section{Struktur Pengendalian Manajemen Struktur}

Sistem merupakan komponen yang berkaitan satu dengan yang lainnya yang secara bersama-sama yang digunakan untuk mewujudkan suatu sistem. Struktur sistem pengendalian manajemen terdiri dari unit-unit yang ada dalam suatu perusahaan yang 
berupa pusat-pusat pertanggungjawaban dan juga 4 ukuran-ukuran (Mulyadi 2001: 3). Jenis-jenis pusat pertanggungjawaban yaitu: 1. Pusat Pendapatan, 2. Pusat Biaya, 3. Pusat Laba, 4. Pusat Investasi.

\section{Proses Pengendalian Manajemen}

Suatu proses pengendalian manajemen terutama berkaitan perilaku. Proses ini melibatkan interaksi antar manajer dan manajer dengan bawahannya. Proses pengendalian manajemen formal meliputi empat kegiatan yaitu: 1. Perencanaan Strategi, 2. Perencanaan Anggaran, 3. Pelaksanaan, 4. Evaluasi Kinerja.

\section{Kinerja Manajerial}

Kinerja adalah hasil kinerja secara kualitas dan kuantitas yang dicapai oleh seorang pegawai dalam melaksanakan tugasnya sesuai dengan tanggung jawab yang diberikan kepadanya (Mulyadi, 2007: 336). Manajemen kinerja (perfomance manajement) adalah alat pemaduan perilaku kerja para karyawan dengan tujuan organisasional. Tidak ada cara tunggal untuk mengelola kinerja.

\section{Budaya perusahaan}

Budaya perusahaan yaitu perilaku dan keyakinan yang membentuk krakteristik perusahaan. Sebuah bisnis keluarga banyak yang akhirnya mengalami kegagalan karena manajemen tidak professional dan tidak memiliki landasan budaya perusahaan yang kuat. Seperti organisasi lainnya, bisnis keluarga mengembangkan cara tertentu dalam menjalankan usahanya yang memberikan keunikan tersendiri pada perusahaan. Pola perilaku yang khusus dan unik tersebut yang akan membentuk budaya perusahaan.

\section{Kepemimpinan}

Kepemimpinan adalah suatu interaksi antara dua orang aatau lebih dalam suatu kelompok yang mengatur atau mengatur ulang situasi, persepsi, dan ekspektasi dari para anggota.

\section{Kinerja Manajemen}


Kinerja berasal dari bahasa job performance atau actual perpormance (prestasi kerja atau prestasi sesungguhnya yang dicapai oleh seseorang atau suatu institusi). Hasil kerja adalahsecara kualitas dan kuantitas yang dicapai oleh seseorang karyawan dalam melaksanakan tugasnya sesuai dengan tanggung jawab yang diberikan kepadanya sedangkan kinerja merupakan hasil pekerjaan yang mempunyai hubungan kuat dengan tujuan strategis organisasi, kepuasan konsumen dan memberikan kontribusi ekonomi. Penilaian kinerja adalah penentuan secara periodik efektivitas operasional suatu organisasi, bagian organisasi, dan karyawannya berdasarkan sasaran, standar, dan kriteria yang telah ditetapkan sebelumnya. Tujuan pokok penilaian kinerja adalah untuk memotivasi karyawan dalam mencapai sasaran organisasi dan dalam memasuki standar perilaku yang telah ditetapkan sebelumnya, agar membuahkan tindakan dan hasil yang diinginkan. Strandar perilaku dapat berupa kebijakan manajemen atau rencana formal yang dituangkan dalam anggaran.

Tujuan dari pengukuran kinerja yakni untuk memotivasi karyawan maupun manajemen dalam mencapai tujuan organisasi dan dalam mematuhi standart perilaku yang telah ditetapkan sebelumnya, agar membuahkan hasil dan tindakan yangdiinginkan.

\section{Pelayanan}

Berdasarkan penjambaran teori dalam penelitian (Prabowo, 2016) Pelayanan adalah upaya untuk membantu, menyiapkan, menyediakan atau mengurus keperluan orang lain. Menurut status keterlibatannya dengan lembaga yang dilayani dapat dibedakan adanya 2 (dua) golongan pelanggan, yakni:1. pelanggan eksternal: semua pelanggan yang berasal dari luar organisasi;2. pelanggan internal: yaitu para karyawan atau unitunit lain di dalam organisasi yang memperoleh pelayanan dari unit yang dimiliki.

\section{Metode penelitian}

Penelitian ini merupakan penelitian explanatory research dengan pendekatan kualitatif. Data yang digunakan dalam penelitian ini berupa data primer yang didapat langsung dari narasumber yaitu Tahu Mekar Group yang berlokasi di Ngunut. Penelitian ini bertujuan untuk mengetahui bagaimana penerapan sistem pengendalian dalam perusahaan keluarga dan dampak yang dihasilkan terhadap kinerja manajemen pada perusahaan keluarga yaitu studi kasus pada Tahu Mekar Group.

Metode analisis data yang dipakai yaitu penelitian lapangan (field research), yaitu 
penelitian yang dilakukan untuk mendapatkan data-data dan informasi yang intern pada perusahaan yang bersangkutan. Data yang diambil sebagian besar diperoleh dengan teknik pengumpulan observasi, wawancara, analisis dokumen. Observasi, yaitu teknik pengumpulan data dengan melakukan serangkaian pengamatan langsung terhadap narasumber. Wawancara, yaitu teknik pengumpulan data dengan melakukan tanya jawab langsung dengan pihak atau bagian-bagian yang berwenang dalam perusahaan tersebut yang behubungan dengan masalah yang dibahas. Dokumentasi, yaitu pengumpulan data yang diperoleh dari catatan - catatan yang dimiliki perusahaan. Teknik ini digunakan untuk memperoleh data tentangdukumen, catatan, dan penerapan sistem pengendalian manajemen . Wawancara dilakukan langsung dengan pemilik dan beberapa karyawan Tahu Mekar Group dilakukan 1 kali tatap muka pada bulan Januari. Observasi dilakukan langsung ke perusahaan dengancara mengamati tanpa ikut serta dalam proses kegiatan perusahaan.

\section{Hasil dan Pembahasan}

\section{Sistem Pengendalian Manajemen di Tahu Mekar Group}

Lembaga Industri Tahu Mekar Group Awal mula bernama Tahu Mekar, karena banyak konsumen yang mengatakan bahwa tahu tersebut apabila digoreng menjadi mekar. Home Industri Tahu Mekar milik Bapak Reni ini berdiri pada tahun 2014. Sebelum mendirikan industri sendiri, Pak Reni bekerja di usaha tahu milik Pak Lurah. Setelah bekerja sudah cukup lama, dan memiliki pengalaman dalam memproduksi tahu, beliau ingin mendirikan usaha sendiri. Modal awal yang digunakan yaitu Rp 10.000.000,00,-. Peralatan yang digunakan pada saat itu masih menggunakan tungku dengan bahan bakar kayu.

Seiring berjalannya waktu, industri tahu mekar milik Pak Reni ini semakin berkembang dan memiliki banyak pelanggan. Karena terkendala sulitnya mencari bahan bakar kayu dalam pemasakannya, maka beliau beralih menggunakan ketel uap. Ketel uap ini menggunakan bahan bakar kayu, tetapi lebih hemat dari pada menggunakan tungku. Juga proses pemasakan kedelai juga lebih cepat sekitar 3 menit sudah mendidih, apabila menggunakan tungku bisa sampat 30 menit baru mendidih. Jadi lebih hemat waktu dan bahan bakar hingga 50\%. Oleh karena itu dalam sehari dapat mengasilkan tahu sebanyak 70 masakan. Beliau juga menerima pesanan tahu untuk kemudian di jual kembali. Saat ini beliau memiliki 20 reseller. Untuk harga reseller per drum nya Rp 77.500,00. Sedangkan harga tahu per bijinya beragam, mulai dari $\mathrm{Rp} 400$, Rp 500, dan Rp 600, tergantung ukuran 
tahunya.

Peningkatan kinerja manajemen ini tentunya dipengaruhi oleh gaya kepemimpinan pemilik. Pemilik selalu berusaha untuk mengingatkan para karyawannya agar selau bekerja sesuai cara yang telah diajarkan. Hal ini merupakan pencegahan agar hasil produksi selalu sempurna dan tidak terlalu banyak hasil produksi yang mengalami kerusakan sehingga meminimalisir komplain dari para pembeli. Terdapat pemisahan tugas yang jelas. Kegiatan pembuatan tahu mekar ini dimulai dari pukul 03.00 pagi hingga pukul 14.00 siang.

Tahapan proses pembuatan tahu ini terdiri dari perendaman, penggilingan, pemasakan, penyaringan, percetakan dan pengepresan, pemotongan tahu. Pertama, kedelai direndam selama 4 jam sambil dicuci secara berkala. Perendaman kedelai bertujuan untuk melunakkan kedelai agar pada saat penggilingan menjadi mudah dan cepat. Kemudian kedelai diging dan dikelupas kulit arinya setelah itu dimasak. Proses pemasakan tahu mekar ini sudah menggunakan ketel uap. Jadi tidak perlu waktu lama hanya membutuhkan waktu 3 menit sudah mendidih, sehingga dapat menghemat waktu dan kayu. Selain dapat menghemat waktu dan kayu, kelebihan lain menggunakan cetel uap yaitu rasa tahu menjadi tidak sangit. Proses pemasakan dengan menggunakan ketel uap ini dilakukan di wadah di bagian bawahnya terdapat pemanas uap dengan bahan bakar yang digunakan adalah kayu bakar. Selanjutnya yaitu proses penyaringan dengan menggunakan kain saring, pada proses ini bubur kedelai sedikit mengental. Saat penyaringan dilakukan penambahan air pada bagian tepi saringan agar tidak ada bubur tahu yang tersisa di saringan.

Proses terakhir dalam pembuatan tahu yaitu percetakan dan pengepresan. Alat yang digunakan untuk mencetak tahu terbuat dari kayu biasanya berukuran 70x70. Tahu yang sudah selesai di cetak dan di pres lalu dikeluarkan dari cetakan dengan cara membalikkan cetakan. Sebelum dipasarkan, tahu terlebih dahulu dipotong sesuai ukuran. Dalam sehari Pak Reni dan karyawan memasak tahu hingga 70 kali masakan. Saat Pak Reni mempunyai 12 karyawan dan 10 reseller yang mengambil tahu dari Pak Reni kemudian dijual kembali. Dalam satu kali masakan menggunakan 5,5 kg kedelai, jadi dalam sehari menggunakan $385 \mathrm{~kg}$ kedelai. Dalam proses pembuatan tahu ini akan menghasilkan ampas tahu, biasanya ampas tahu dibeli oleh tetangga untuk pakan ternak. Jenis kedelai yang digunakan dan kelembutan sari kedelai sangat mempengaruhi proses pembuatan tahu. Semakin lembut sari kedelai yang dihasilkan, maka semakin banyak protein yang dapat digumpalkan dan semakin sedikit ampas yang dihasilkan. Tahu yang diproduksi 
oleh tahu mekar ini tersedia dalam bermacam ukuran dengan harga yang berbeda. Harga yang patok per biji nya yaitu Rp 400,00,- Rp 500,00,- dan Rp 600,00,-.. Pemilik sepenuhnya menyadari bahwa apabila setiap pegawai memiliki fokus pekerjaan masingmasing maka hasilnya akan lebih efektif dan efisien.

Gaya kepemimpinan yang ada pada Tahu Mekar Group ini adalah kepemimpinan terpusat. Segala peraturan dan perintah bersumber dari pemilik yaitu pak Reni. menurut hasil wawancara yang dilakukan dengan beberapa karyawan Tahu Mekar Group, pemilik merupakan orang yang sangat ramah dan peduli terhadap karyawan. Meskipun begitu pemilik tetap memiliki ketegasan dalam menjalankan perusahaan. Pak Reni tidak segan menegur karyawan yang melakukan kesalahan. Dalam kesehariannya, beliau tidak menjaga jarak dengan karyawan, tidak membedakan karyawan berdasarkan jabatannya, semua dianggap sama rata.

Faktor lain yang juga mempengaruhi kinerja manjemen pada Tahu Mekar Group yakni budaya organisasi. Hal ini tidak lepas dari peranan pemilik yang selalu berusaha menanamkan nilai gotong royong kepada para karyawan, sehingga rasa solidaritas yang tinggi antara para karyawan terbentuk secara alamiah. Seperti, saat salah satu karyawan sedang sakit maka seluruh karyawan termasuk pemilik akan mengumpulkan uang iuran untuk menjenguk. Karyawan saling menghargai satu samalain dan menimbulkan rasa kekeluargaan dalam bekerja. Sehingga tidak pernah terjadi konflik antar pegawai maupun dengan pemilik. Setiap satu bulan sekali diadakan rapat yang membahas cara untuk dapat menghasilkan produk yang lebih baik, dalam diskusi setiap karyawan berhak menyampaikan pendapatnya. Seringkali diskusi diadakan dengan makan bersama dengan seluruh karyawan. Pemilik selalu berupaya menghargai karyawannya dan menciptakan lingkungan kerja yang nyaman bagi para karyawan.

Penerapan sistem pengendalian manajemen yang ada di perusahaan sebetulnya sudah cukup baik meskipun perusahaan tidak sepenuhnya menyadari bahwa yang dilakukan merupakan bentuk suatu sistem pengendalian.

Tidak terdeteksinya sistem ini dikarenakan kurangnya pemahaman pemilik akan sistem ini dan manfaatnya, karena kembali lagi perusahaan keluarga sering kali menghindari penerapan hal-hal yang dianggap memperumit pekerjaan, yang terpenting bagi perusahaan semacam ini adalah perusahaan tetap beroperasi dan memperoleh keuntungan. Tapi hal ini memang wajar karena perlu diingat penerapan sistem yang detail pada perusahaan publik dikarenakan skala bisnis yang besar berbeda dengan perusahaan keluarga yang kebanyakan merupakan usaha skala kecil menengah, perusahaan bisa 
merangkul seluruh karyawan meskipun tanpa penerapanpengendalian yang detail.

Meskipun begitu masih terdapat banyak kekurangan dalam pengendalian manajemen yang ada pada Tahu Mekar Group, perusahaan ini dijalankan dengan mindset yang masih tradisional sehingga belum bisa memberikan apresiasi kepada karyawan yang memiliki kinerja lebih dari yang lain. Setiap karyawan diangggap sama rata dalam kompetensinya melakukan pekerjaan. Padahal apabila hal ini diperhatikan akan bermanfaat bagi perusahaan, contohnya saja apabila karyawan yang kinerjanya bagus diberi penghargaan berupa bonus atau promosi jabatan maka karyawan akan lebih semangat dalam bekerja sehingga target produksi setiap harinya bisa tercapai. Apabila target produksi selalu mengalami peningkatan maka hal ini akan mempengaruhi penjualan dan laba perusahaan, dengan kata lain kinerja manajemen mengalami peningkatan. Selain lemahnya apresiasi terhadap karyawan, Tahu Mekar Group juga tidak memiliki sistem absen bagi para karyawan.

Apabila perusahaan mau berusaha untuk menerapkan pengendalian secara lebih baik maka hal ini akan sangat bermanfaat bagi perusahaan. Jika dengan pengendalian manajemen yang kurang terstruktur saja perusahaan keluarga tetap mampu berkembang, maka apabila diterapkan sistem pengendalian yang lebih terstruktur maka peluang peningkatan kinerja perusahaan menjadi semakin tinggi.

\section{Faktor - Faktor yang Mempengaruhi Loyalitas Karyawan}

\section{Kompensasi}

Kompensasi yang diberikan secara langsung, yaitu gaji maupun insentif yang berupa komisi. Perusahaan yang mampu memenuhi kebutuhan karyawannya dengan kompensasi dan insentif yang diberikan, maka karyawan akan cenderung memiliki loyalitas terhadap perusahaan. Kompensasi dapat mendorong peningkatakan produktivitas kerja karyawan, dan merupakan salah satu faktor penting yang mendorong karyawan loyal terhadap perusahaan.

\section{Rasa Kekeluargaan}

Rasa kekeluargaan yang ada di perusahaan sangat terasa di antara anggota badan usaha. Keakraban antara karyawan dengan pemimpin tercipta dengan adanya kebersamaan diantara anggota badan usaha, terkadang diadakannya makan siang bersama karyawan. Rasa kekeluargaan yang sudah melekat akan membuat karyawan betah untuk 
bekerja di perusahaan, karena akan membuat karyawan menganggap bahwa anggota badan usaha sudah seperti keluarga sendiri.

\section{Tempat Kerja yang Nyaman}

Adanya suasana kerja yang menyenangkan bagi karyawan membuat mereka dapat melaksanakan pekerjaanya dengan baik. Suasana kerja yang menyenangkan dapat membuat karyawan menjadi loyal pada perusahaan serta berguna untuk pertumbuhan jangka panjang perusahaan. Rasa nyaman yang tercipta di lingkungan perusahaan dapat menjadi acuan bagi karyawan untuk bekerja lebih baik. Rasa nyaman dengan sendirinya akan menimbulkan kedekatan, kebahagiaan, dan rasa memiliki. Jika karyawan memiliki hal ini, maka dengan sendirinya loyalitas karyawan akan meningkat.

\section{Rekan Kerja yang Bersahabat}

Kepedulian atau rasa solidaritas diantara karyawan sangat kuat, hal ini dilihat dari kerjasama yang baik antar karyawan terlihat dari saling membantu karyawan jika ada kesulitan dalam bekerja. Rasa kebersamaan dan solidaritas yang tinggi diantara anggota badan usaha akan menciptakan suasana satu tim kerja yang solid. Dengan kerjasama yang solid dari semua sumber daya akan memberikan dampak positif bagi perusahaan yaitu perusahaan dapat mencapai bahkan melampaui target kerja.

\section{Gaya Kepemimpinan}

Suatu perusahaan dapat berjalan baik dan berhasil mencapai tujuan yang diinginkan tergantung kualitas pemimpin yang tercermin dalam gaya kepemimpinannya yang berupa sikap dan tindakan terhadap karyawan dan anggotanya. Kepemimpinan yang efektif sangat penting untuk kelangsungan dan keberhasilan suatu badan usaha. Loyalitas karyawan akan mengingkat sesuai dengan kepemimpinan yang tepat.

Jadi selain kompensasi, kekeluargaan, tempat kerja yang nyaman, dan rekan kerja yang bersahabat, kepemimpinan juga mempunyai peranan yang sangat penting terhadap loyalitas karyawan, karena keberhasilan seorang pemimpin perusahaan dalam menggerakkan karyawannya dalam mencapai tujuan yang telah ditetapkan oleh perusahaan sangat tergantung kepada pemimpin itu sendiri dalam menciptakan loyalitas anggota badan usahanya. Loyalitas karyawan akan mengingkat sesuai dengan kepemimpinan yang tepat. 


\section{Sistem Pengendalian Manajemen terhadap Loyalitas Karyawan}

\section{a. Pengendalian Hasil}

Dengan target yang ditetapkan tidak dijadikan sebagai sebuah beban, karena ada sosok pemimpin yang tidak lepas tangan terhadap anggotanya dan selalu mendorong serta memotivasi karyawannya. Dorongan atau motivasi yang diberikan atasan kepada karyawan sangat diperlukan untuk pencapaian target yang ditetapkan oleh perusahaan, karena dengan motivasi yang diberikan dapat menyemangati karyawan sehingga akan berdampak pada kinerja yang menjadi lebih baik.

Pengendalian hasil yang diterapkan oleh perusahaan memiliki dampak terhadap loyalitas karyawan, karena dengan adanya reward dan punishment yang diterapkan oleh perusahaan maka karyawan akan lebih bertanggungjawab terhadap pekerjaan yang menjadi tugasnya. Karyawan akan merasa puas dengan reward yang diterimanya sesuai dengan kinerja yang telah diberikannya kepada perusahaan, sehingga karyawan dapat memberikan yang terbaik untuk perusahaan. Kepuasan ini dapat mendorong peningkatakan produktivitas kerja karyawan dan mencegah terjadinya perpindahan karyawan ke perusahaan lain, hal ini menjadikan karyawan semakin loyal terhadap perusahaan. Dengan adanya loyalitas dari karyawan maka akan berdampak pada produktivitas perusahaan yang semakin meningkat dan tujuan yang telah ditetapkan oleh perusahaan dapat tercapai. Jadi adanya hubungan timbal balik, dimana karyawan mendapat imbalan dan organisasi dapat mencapai tujuannya. Dapat dikatakan bahwa karyawan dan perusahaan mendapatkan keuntungan masing-masing.

\section{b. Pengendalian Proses}

Pengendalian proses yang diterapkan di perusahaan untuk mendorong karyawan agar patuh terhadap organisasi dalam melaksanakan aktivitasnya dengan menggunakan standard operating procedures. Keberadaan standard operating procedures yang merupakan suatu aturan atau prosedur yang berlaku dan mempermudah karyawan untuk menjalankan tugasnya, sehingga karyawan menjalankan tugasnya tanpa raru-ragu dan tanpa beban, karena tujuan perusahaan membuat standard operating procedures bukan untuk mempersulit tapi mempermudah pekerjaan. Standard operating procedures bisa menjadi alat pengendalian dalam menilai kinerja seseorang dari proses pekerjaan yang mereka lakukan. Karyawan yang loyal kepada perusahaan akan patuh kepada standard operating procedures yang berlaku di perusahaan. 


\section{c. Pengendalian Budaya}

Jika ingin berhasil dan dapat mencapai tujuannya, maka perusahaan harus mempunyai strategi dalam mengikat karyawan agar tidak kehilangan karyawan terbaiknya. Pengendalian budaya yang diterapkan oleh perusahaan memiliki dampak terhadap loyalitas karyawan, karena kedekatan antara atasan dengan anggota badan usaha sangat membantu untuk membangun rasa kekeluargaan di antara mereka, sehingga karyawan merasa dianggap sebagai bagian dari perusahaan tersebut. Rasa simpatik dari karyawan kepada atasan akan muncul ketika atasan yang mau bergaul dengan dengan karyawan. Sikap atasan seperti itu, dapat mempererat rasa kekeluargaan di antara anggota badan usaha. Dengan kata lain pendekatan pribadi ini dapat menciptakan hubungan yang erat dan memperkokoh hubungan antara atasan dengan karyawan. Ini merupakan salah satu strategi untuk mengikat karyawan yang bekerja di perusahaan. Hal ini sesuai dengan (Efferin, 2010) yang mengatakan dengan pendekatan pribadi yang efektif, maka bawahan mempunyai kebanggaan, rasa dihargai atau dikasihi, dan menjadikan bawahan akan lebih loyal terhadap pemimpin dan organisasinya. Selain itu, perusahaan harus memberikan pelatihan kepada karyawan. Perusahaan atau pemimpin yang peduli terhadap perkembangan karyawan merupakan satu hal yang penting, karena karyawan akan merasa diperhatikan. Untuk menjaga karyawan maka harus dipastikan bahwa karyawan bisa berkembang dalam bakat yang dimilikinya, harus bisa meningkatkan gairah dalam bekerja. Jadi karyawan memilih untuk bertahan di perusahaan, karena mereka merasa pemimpin peduli terhadap kemajuan mereka dan perusahaan menjadi tempat untuk belajar dan dapat mengembangkan diri mereka.

Loyalitas merupakan dasar bagi seorang karyawan untuk dapat bertahan di suatu perusahaan dan memberikan yang terbaik untuk perusahaan. Perusahaan yang memiliki karyawan yang loyal, maka akan menjadikan perusahaan semakin kuat dan dapat mengikuti persaingan yang semakin ketat dalam dunia usaha saat ini. Tentunya setiap perusahaan pasti mengharapkan loyalitas dari karyawan, karena dengan adanya loyalitas

yang diberikan karyawan terhadap perusahaan akan menjadi kunci untuk meningkatkan kualitas kerja karyawan sehingga tujuan perusahaan dapat tercapai.

Penerapan sistem pengendalian manajemen dapat menyelaraskan tindakan atau perilaku anggota badan usaha sehingga sesuai dengan kepentingan perusahaan. Sistem pengendalian manajemen akan menjadi sarana bagi pemimpin dalam melaksanakan fungsi pengendaliannya dan menjadi sarana dalam menyalurkan nilai-nilai perusahaan 
kepada karyawan. Jika sistem pengendalian manajemen yang diterapkan sudah efektif, maka dalam bekerja karyawan akan merasa nyaman sehingga tidak menutup kemungkinan loyalitas karyawan akan meningkat, apabila loyalitas telah meningkat dan kenyamanan kerja telah tercipta, hal ini dapat mendorong peningkatakan produktivitas kerja karyawan, tentunya akan mendorong tercapainya tujuan utama dari perusahaan.

Budaya yang tercipta dalam organisasi inilah yang ditransmisikan oleh seorang pemimpin kepada anggotanya dan dapat berpengaruh yang kuat pada perusahaan keluarga. (Efferin, 2010), Budaya yang tercipta akan menjadi pengendali perilaku organisasi dan dari budaya organisasi menghasilkan pengendalian informal dalam organisasi. Pengendalian budaya dapat dikatakan sebagai alat pengendalian yang mengarahkan anggota badan usaha melalui serangkaian budaya yang ditanamkan pada badan usaha tersebut agar konsisten dengan tujuan perusahaan. Pengendalian budaya yang terbentuk melalui budaya organisasi yang baik dan kuat. Budaya yang tercipta dalam organisasi dapat menjadi kunci penting yang dapat digunakan untuk mengarahkan jalannya perusahaan, karena semakin baik dan kuat budaya organisasi dari suatu perusahaan maka kebijakan dan peraturan yang dibutuhkan semakin sedikit. Kombinasi yang benar antara pengendalian formal dan informal, akan mengarah pada sistem pengendalian yang efektif, memungkinkan pemimpin memenangkan hati dan pikiran karyawan.

Pemimpin harus mampu menanamkan budaya organisasi yang ada kepada karyawan dan menjadikan karyawan merasa menjadi bagian dari keluarga sehingga dapat menciptakan kepedulian yang lebih terhadap perusahaan dan karyawan bersedia untuk saling mengingatkan untuk menjaga dan menjalankan nilai-nilai yang ada di perusahaan tersebut sehingga tujuan perusahaan dapat tercapai. Pemimpin juga harus mampu menciptakan komitmen organisasi kepada karyawan dengan menanamkan nilai-nilai perusahaan, memotivasi karyawan, dan kepuasan kerja karyawan. Pemimpin harus bisa memenangkan hati karyawan, karena dengan memenangkan hati karyawan pemimpin dapat mendapatkan loyalitas dari karyawan tersebut. Karyawan yang memberikan kepercayaan dan rasa hormat kepada pemimpin dan dikombinasikan dengan metode untuk menciptakan pengendalian budaya, maka hal ini akan mempercepat dan memperkuat internalisasi nilai-nilai kepada karyawan.

Pendekatan pribadi yang efektif akan membuat karyawan mempunyai kebanggaan, rasa dihargai atau dikasihi, dan menjadikan bawahan akan lebih loyal terhadap pemimpin dan organisasinya. Dengan adanya kedekatan antara atasan dengan karyawan akan 
membuat karyawan merasa menjadi bagian dari keluarga, sehingga akan tercipta suasana kerja yang kondusif yang nantinya akan berdampak pada loyalitas. Rasa kekeluargaan yang ada akan menciptakan rasa nyaman diantara anggota badan usaha, sehingga dengan sendirinya akan membuat karyawan dapat bekerja dengan baik dan akan menumbuhkan kedekatan di antara anggota badan usaha, kebahagiaan, dan rasa memiliki, sehingga mereka akan saling mendukung dan bisa diajak kerjasama sehingga tercipta suasana kerja yang kondusif, maka dengan sendirinya akan membuat karyawan memiliki loyalitas terhadap perusahaan.

Apabila karyawan memiliki sikap loyalitas maka karyawan tersebut memiliki keinginan yang kuat untuk tetap menjadi anggota badan usaha tersebut meskipun terdapat kesempatan untuk bekerja di tempat lain, mempunyai suatu usaha yang lebih untuk organisasinya dan memberikan yang terbaik untuk perusahaannya. sikap loyalitas yang dimiliki karyawan dapat diketahui dengan adanya pengakuan bahwa bekerja untuk organisasi merupakan pilihan terbaik mereka.

Selain dengan rasa nyaman dan rasa kekeluargaan yang ada di perusahaan yang membuat karyawan menjadi loyal, untuk menjaga karyawan maka harus dipastikan bahwa karyawan bisa berkembang dalam bakat yang dimilikinya, harus bisa meningkatkan gairah dalam bekerja, dan memberikan kompensasi. Ketiganya ini harus seimbang jika ingin meningkatkan loyalitas karyawan, karena dengan adanya loyalitas maka karyawan akan melakukan yang terbaik untuk perusahaan dan mereka menganggap bahwa bekerja untuk organisasi merupakan pilihan terbaik mereka. Jadi dapat dikatakan bahwa dengan adanya loyalitas dalam diri karyawan maka ini merupakan suatu keuntungan bagi perusahaan, karena karyawan menjadi lebih setia dan peduli terhadap perusahaan. Dengan adanya loyalitas ini membuat karyawan memberikan kontribusi yang lebih untuk tumbuh kembangnya perusahaan, sehingga hal ini dapat memudahkan perusahaan untuk mewujudkan tujuan perusahaan.

\section{Kesimpulan dan Saran}

Peningkatan kinerja manajemen terjadi karena beberapa faktor. Salah satu faktor yang sangat mempengaruhi peningkatan kinerja manajemen pada Tahu Mekar Group adalah gaya kepemimpinan dan budaya organisasi. Meskipun tidak secara langsung diketahui oleh pemilik akan tetapi hasil penelitian menunjukkan bahwa pengendalian manajemen yang dilakukan oleh perusahaan sudah cukup baik sehingga mempengaruhi 
peningkatan kinerja manajemen terbukti dari analisis laporan keuangan dapat dilihat bahwa perusahaan terus mengalami perkembangan. Gayakepemimpinan pemilik yang selalu berusaha memperhatikan karyawan serta budaya organisasi yang menciptakan lingkungan kerja yang nyaman memberikan motivasi karyawan untuk bekerja lebih giat dan mempengaruhi peningkatan kinerja manjemen.Dengan memperhatikan hal tersebut sebaiknya perusahaan mulai memberikan perhatian terutama untuk penambahan wawasan untuk mempelajari suatu hal baru untuk perkembangan perusahaan. Tidak hanya terpaku pada sistem yang sudah dijalankan secara turun temurun tapi berusaha memperbaiki menjadi lebih baik. Proses pembelajaran juga bisa dimanfaatkan sebagai asset yang berharga bagi perusahaan keluarga dengan tidak mengubah kedekatan hubungan yang selama inimenjadi ciri khas perusahaan keluarga. 


\section{Daftar Pustaka}

Anthony dan Govindrajan (2002) Sistem Pengendalian Manajemen. Jakarta: Salemba Empat.

Efferin, S. dan S. (2010) Seni Perang Sun Zi dan Sistem Pengendalian Manajemen Filosofi dan Aplikasi. Jakarta: PT Elex Media Komputindo.

Halim, Abdul, Achmad Thahjono, dan M. H. (2003) Sistem Pengendalian Manajemen. Edisi Kedu. Jogjakarta: Akademi Manajemen Perusahaan YKPM.

Mariyana, Karolin, Wiyono Pontjoharyo. (2013) 'Analisis Gaya Kepemimpinan terhadap Penerpan Result Control pada Divisi Plywood Badan Usaha Keluarga PT. X di Surabaya', Vol 2.

Merchant Kenneth A. dan Van der Stede (2014) Sistem Pengendalian Manajemen. Edisi Tiga. Jakarta: Salemba Empat.

Prabowo, R. G. M. (2016) 'Indeks Kepuasan Masyarakat Terhadap Pelayanan Kantor Desa Bandung Kabupaten Tulungagung', Benefit, 3(1), pp. 75-92.

Purnama, A. (2013) 'Peranan Gaya Kepemimpinan dan Sistem Pengendalian Manajemen terhadap Loyalitas Karyawan di Perusahaan Keluarga PT. SUS Surabaya', Vol 2. 